\title{
ANALYTICAL, NUMERICAL AND EXPERIMENTAL STRESS ASSESSMENT OF THE SPHERICAL TANK WITH LARGE VOLUME
}

\author{
Radovan Petrović, Miroslav Živković, Marko Topalović, Radovan Slavković
}

Original scientific paper

This paper presents designing of spherical tank using combination of analytical procedure with FEM analysis and experimental testing in order to minimize design time and verify design strength. Analytical procedure for calculation of the tank strength in the initial stages of design process is briefly presented. Based on analytical results, tank is dimensioned and FEM model is created. FEM analysis is used to identify areas with high concentration of stresses. FEM results showed that equivalent value of stress at the points of spherical tank support exceeds the values of yield stress, but this exceedance is not significant and in very small area, so overall design was deemed worthy. Experimental measurements verified FEM results that it is not necessary to reinforce the spherical tank at the points of support. After 8 months experiments were repeated giving the same results as the original measurements, thus justifying decision not to reinforce tank supports.

Keywords: analytical stress assessment; experimental testing; Finite Element Method (FEM); spherical tank

Analitička, numerička i eksperimentalna procjena naprezanja kuglastog spremnika velikog obujma

Izvorni znanstveni članak U radu se opisuje konstruiranje kuglastog spremnika kombinacijom analitičkog postupka s FEM analizom i eksperimentalnim testiranjem kako bi se smanjilo vrijeme konstruiranja i provjerila proračunska čvrstoća. Kratko je prikazan analitički postupak proračuna čvrstoće spremnika u početnim stadijima konstruiranja. Na temelju analitičkih rezultata određuju se dimenzije spremnika i kreira FEM model. Za prepoznavanje područja s visokom koncentracijom naprezanja koristi se FEM analiza. FEM rezultati su pokazali da ekvivalentna vrijednost naprezanja na potpornim točkama spremnika prelazi vrijednosti granice popuštanja, ali to nije značajno i na veoma je maloj površini pa se cjelokupna konstrukcija smatra važećom. Eksperimentalna su mjerenja potvrdila FEM rezultate da nije potrebno pojačati kuglasti spremnik na potpornim točkama. Nakon 8 mjeseci eksperimenti su bili ponovljeni, dajući iste rezultate kao i originalna mjerenja i tako potvrdili odluku da se ne pojačavaju potporne točke spremnika.

Ključne riječi: analitička procjena naprezanja; eksperimentalno testiranje; kuglasti spremnik; metoda konačnih elemenata (FEM)

\section{Introduction}

The spherical tank (Fig. 1) belongs to the group of stable elevated tanks designed for storing butane, propane or mixture of propane-butane with medium pressure $[1 \div 3]$.

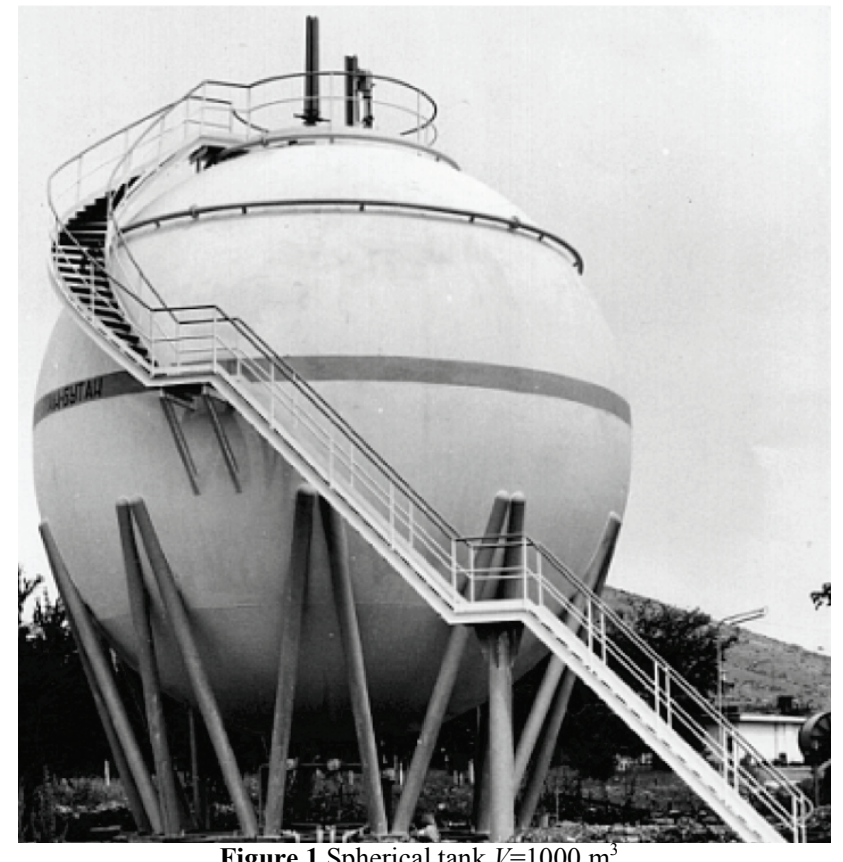

Figure 1 Spherical tank $V=1000 \mathrm{~m}$

These highly flammable gases need to be stored in tanks designed with safety as their upmost priority [4]. The spherical tank is loaded with the fluid pressure, hydrostatic pressure [5] and forces that arise due to its own weight. In addition to these constant loads, other loads may occur due to the action of wind force [6], snow [7] as well as seismic loads [8, 9]. To prevent leakage or fire of those hazardous gases, detection of damage in tank structure is crucial [5]. However, good tank design, and adhering to safety protocols can prevent critical damage from ever occurring in tank structure. To ensure there are no flaws in their design, engineers cannot rely solely on analytical results, they need to verify their design by numerical simulations and experimental testing as well, which is methodology presented in this paper.

Well known analytical procedure used in designing spherical tanks is briefly explained [10]. Detailed derivation of expressions for membrane forces and stresses in the direction of the tangent to the circle of the parallel and the meridian using the membrane state of stress and equilibrium equations for the shell in the form of surface of revolution is given in [11]. Analytical solution is used in the initial phase of design because the basic dimensions of the spherical tank can be obtained in a relatively short period of time [10], but this solution does not account for specificity of areas with high concentration of stress, such as points of connection between tank and its supports, and therefore more detailed numerical analysis is required in order to be certain that proposed design will meet safety criteria. This analysis is done using Finite Element Method (FEM) and its results show that equivalent value of stress at some points exceeds the values of yield stress. Areas of plastic deformation are not significant in comparison to the entire spherical tank construction, so based on FEM results it is concluded that cumulating of plastic deformation will not 
occur. Since FEM results should always be used with caution, having in mind that their accuracy depends on number of factors such as mesh quality, proper constraints, loads and boundary conditions, experimental verification of FEM results in the most critical areas of the tank structure was required in order to verify conclusions drawn from FEM results. Achieved high level of correspondence between results obtained analytically, with FEM analysis, and with experimental tests of spherical tank show that the proposed design meets safety standards. After eight months of exploitation, experimental testing was repeated, and no changes in stress values were observed. Combination of analytical procedure with FEM analysis and experimental testing of spherical tank gives more detailed insight in behavior of tank construction in most critical areas in comparison to design process which rely solely on analytical results and thus ensuring optimum design and safe usage during envisioned operating life time.
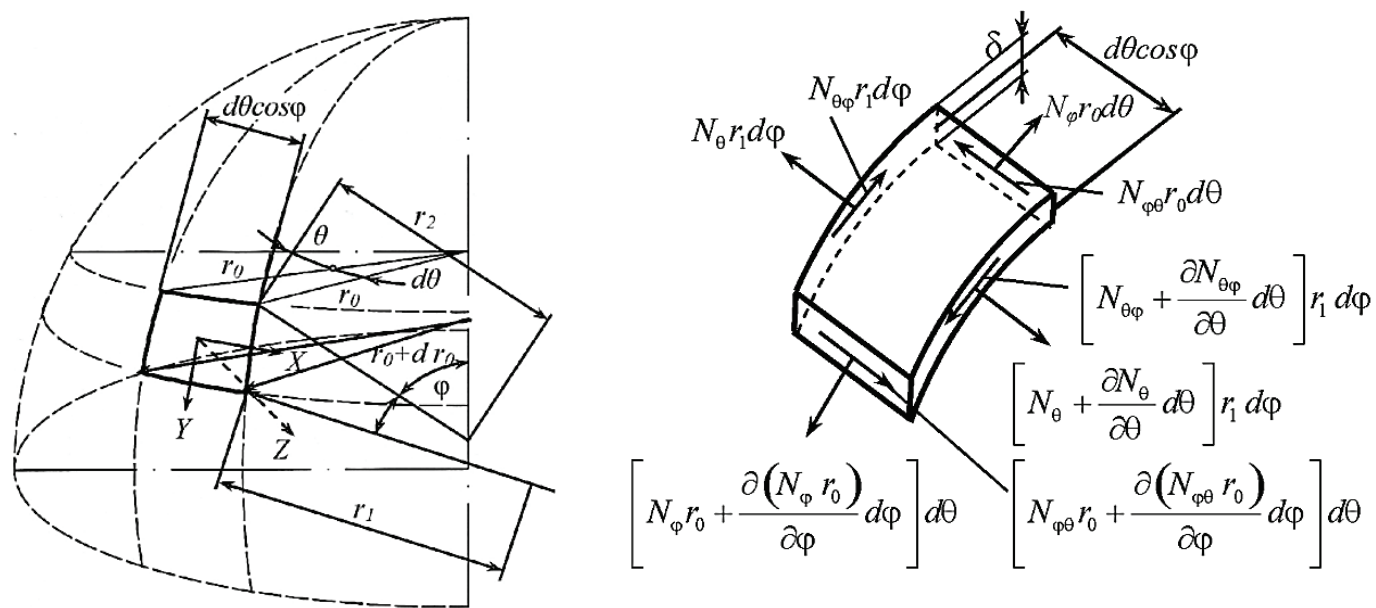

Figure 2 a) Position of the shell in the form of surface of revolution element, b) Internal forces in the element of the shell in the form of surface of revolution

According to [11], equilibrium equations for the shell element are given with:

$\frac{\partial N_{\theta}}{\partial \theta} r_{1}+N_{\theta \varphi} r_{1} \cos \varphi+\frac{\partial\left(N_{\varphi \theta} r_{0}\right)}{\partial \varphi}+X r_{0} r_{1}=0$

(1)

$$
\begin{aligned}
& \frac{\partial N_{\theta \varphi}}{\partial \theta} r_{1}-N_{\theta} r_{1} \cos \varphi+\frac{\partial\left(N_{\varphi} r_{0}\right)}{\partial \varphi}+X r_{0} r_{1}=0, \\
& \frac{N_{\theta}}{r_{2}}+\frac{N_{\varphi}}{r_{1}}=-Z .
\end{aligned}
$$

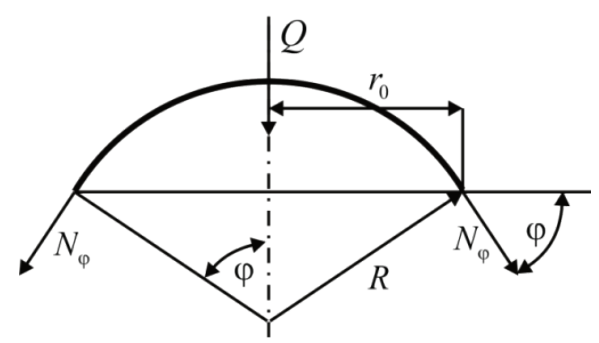

Figure 3 Equilibrium of the shell section

Equilibrium between internal forces and external load acting on shell section is shown in Fig. 3 .

\section{Methods}

\subsection{Analytical procedure}

Stress state in elements of the shell in the form of surface of revolution can be determined by Equilibrium equations for the shell elements.

Forces acting on the element which is a part of shell in the form of surface of revolution are presented in Figure 2. The element is defined by two parallel circles, with radiuses $r_{0}$ and $r_{0}+d r_{0}$, and two adjacent meridians determined by the angles $\theta$ and $\theta+d \theta$. Position of the element belonging to the shell in the form of surface of revolution for spherical tank is shown in Fig. 2a as well as components of the external surface load $X, Y, Z$. Fig. 2b shows internal forces acting on that element $[10,11]$. The tank operates in moderate climate conditions, so temperature influence can be neglected [12]
Equilibrium equation for shell section is given by

$2 \pi R N_{\varphi} \sin ^{2} \varphi+Q=0$,

where $Q$ represents resultant of external loading.

\subsubsection{Own weight loading}

The load on the spherical tank due to its own weight is shown in Fig. 4.

Position of tank supports is defined by angle $\varphi_{0}$ (Fig. 4).

Internal forces due to tank own weights above supports are:

$$
\begin{aligned}
& N_{\varphi}=-\frac{g R}{1+\cos \varphi}, \\
& N_{\theta}=-g R \cdot\left(\cos \varphi-\frac{1}{1+\cos \varphi}\right)
\end{aligned}
$$

Internal forces due to tank own weight below supports are: 


$$
\begin{aligned}
& N_{\varphi}=-\frac{g R}{1-\cos \varphi}, \\
& N_{\theta}=-g R \cdot\left(\cos \varphi-\frac{1}{1-\cos \varphi}\right) .
\end{aligned}
$$

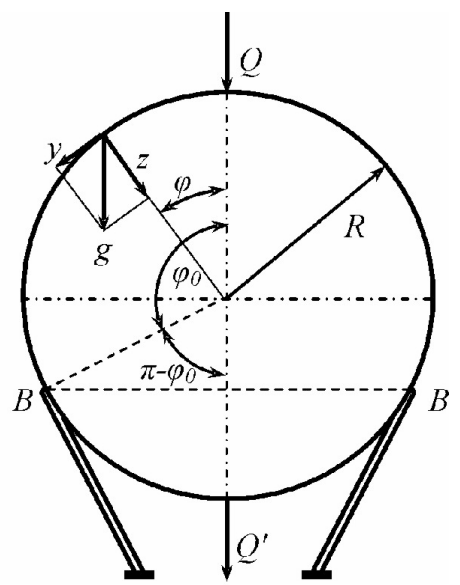

Figure 4 Own weight loading of the spherical tank

\subsubsection{Internal pressure loading}

Spherical tank supported along a parallel circle B-B (Fig. 4) and filled with liquid which has specific weight $\gamma$, is loaded with pressure:

$p=-Z=\gamma R(1-\cos \varphi)+p_{g}$,

where $p_{g}$ represents uniformed pressure superposed on hydrostatic pressure [11].

Internal forces due to hydrostatic pressure and internal gas pressure above supports are:

$N_{\varphi}=\frac{\gamma R^{2}}{6}\left(1-\frac{2 \cos ^{2} \varphi}{1+\cos \varphi}\right)+\frac{R p_{g}}{2}$,

$N_{\theta}=\frac{\gamma R^{2}}{6}\left(5-6 \cos \varphi+\frac{2 \cos ^{2} \varphi}{1+\cos \varphi}\right)+\frac{R p_{g}}{2}$.

Internal forces due to hydrostatic pressure and internal gas pressure below supports are:

$$
\begin{aligned}
& N_{\varphi}=\frac{\gamma R^{2}}{6}\left(5+\frac{2 \cos ^{2} \varphi}{1-\cos \varphi}\right)+\frac{R p_{g}}{2}, \\
& N_{\theta}=\frac{\gamma R^{2}}{6}\left(1-6 \cos \varphi-\frac{2 \cos ^{2} \varphi}{1-\cos \varphi}\right)+\frac{R p_{g}}{2} .
\end{aligned}
$$

\subsection{Finite element simulation}

Verification of analytical expressions using finite element method was performed for the spherical tank with volume $V=1000 \mathrm{~m}^{3}$, external diameter $D=12456 \mathrm{~mm}$, wall thickness $\delta=28 \mathrm{~mm},[13 \div 16]$. The tank is made of steel whose yield stress is:

$f_{y}=R_{E H}=419 \mathrm{~N} / \mathrm{mm}^{2}$.
The operating pressure in the tank is: $p_{g}=1,67 \mathrm{MPa}$. For safety reasons, experimental testing was performed with water $\left(\gamma=9810 \mathrm{~N} / \mathrm{m}^{3}\right)$ instead of propane-butane mixture. Analytical calculation and FEM simulations were also done with water in order to obtain comparable results. Using $(7 \div 13)$ and expressions for stresses:

$\sigma_{\varphi}=\frac{N_{\varphi}}{\delta}, \sigma_{\theta}=\frac{N_{\theta}}{\delta}$

corresponding values of forces and stresses for different angles are obtained. The total value of stresses can be calculated by adding the own weight and internal pressure

\begin{tabular}{|c|c|c|c|}
\hline Angle $\varphi /^{\circ}$ & $\sigma_{\varphi} / \mathrm{MPa}$ & $\sigma_{\theta} / \mathrm{MPa}$ & $\sigma_{e} / \mathrm{MPa}$ \\
\hline 0 & 185,3 & 185,3 & 185,3 \\
\hline 10 & 185,4 & 185,5 & 185,4 \\
\hline 20 & 185,5 & 185,9 & 185,7 \\
\hline 30 & 185,8 & 186,7 & 186,2 \\
\hline 40 & 186,1 & 187,8 & 186,9 \\
\hline 50 & 186,5 & 189,1 & 187,8 \\
\hline 60 & 186,8 & 190,7 & 188,8 \\
\hline 70 & 187,2 & 192,5 & 189,9 \\
\hline 80 & 187,5 & 194,5 & 191,1 \\
\hline 90 & 187,6 & 196,8 & 192,4 \\
\hline 100 & 196,9 & 189,9 & 193,5 \\
\hline 110 & 197,2 & 191,9 & 194,6 \\
\hline 120 & 197,6 & 193,7 & 195,7 \\
\hline 130 & 198,0 & 195,3 & 196,6 \\
\hline 140 & 198,3 & 196,6 & 197,5 \\
\hline 150 & 198,6 & 197,7 & 198,2 \\
\hline 160 & 198,9 & 198,5 & 198,7 \\
\hline 170 & 199,0 & 198,9 & 199,0 \\
\hline 180 & 199,1 & 199,1 & 199,1 \\
\hline
\end{tabular}
components. The resulting values are presented in Tab. 1 and Fig. 5.

Table 1 The stresses due to own weight and internal pressure

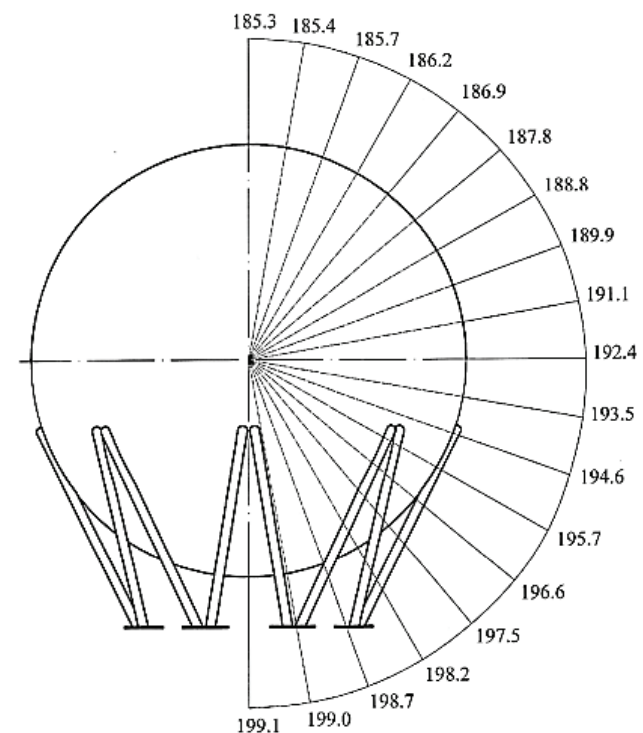

Figure 5 Distribution of values of the equivalent stress of the spherical tank obtained analytically

The 3D model of the spherical tank was formed by synthesis of $3 \mathrm{D}$ models of all structural parts $[17 \div 20]$. The model represents a continuum discredited by 10 -node tetrahedral elements for the purpose of creating the FEM model (45 124 nodes. 25016 elements). The equivalent 
stress field is presented in Fig. 6. The distribution of equivalent stresses of the FEM analysis corresponds to the distribution of stresses obtained by analytical calculation.

The highest values of stresses were obtained at the points of support of the spherical tank (Fig. 7) [20].

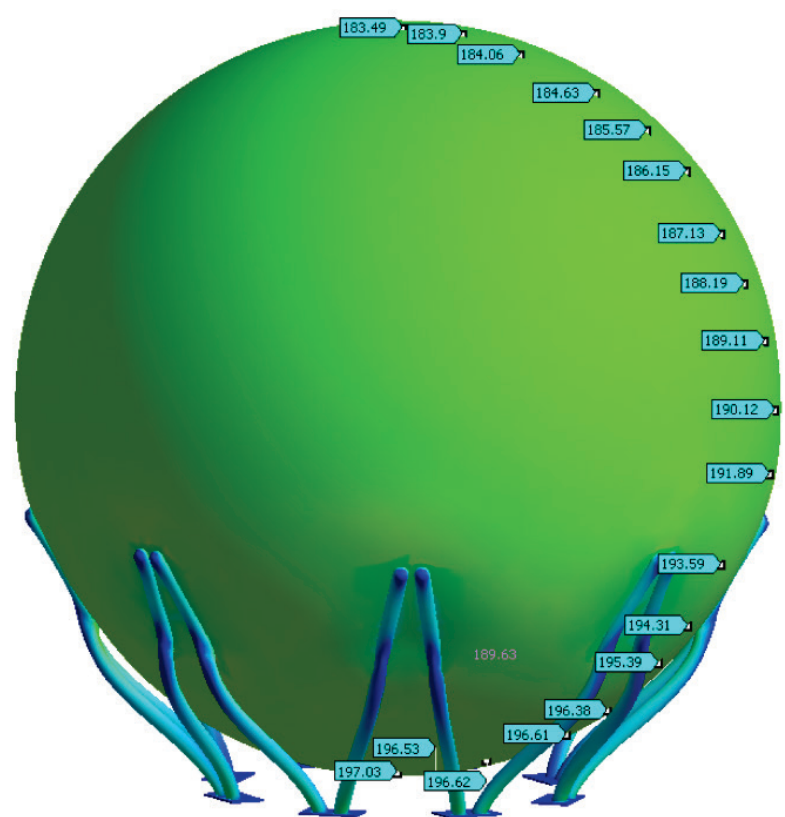

Figure 6 Distribution of values of the equivalent stress of the spherical tank by using the FEM model

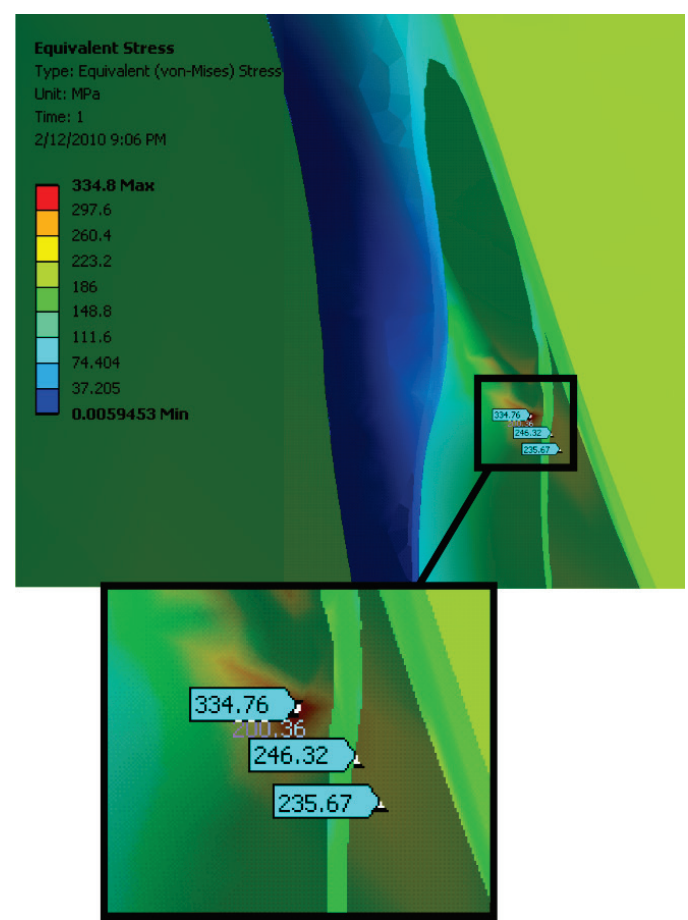

Figure 7 Distribution of the equivalent stress of the spherical tank at the points of support

These values are higher than yield stress and could cause failure of tank supports. Since the area of this high stress concentration is very small it is concluded that the overall strength of supports will not deteriorate with time due to cumulating of plastic deformation. Deformations of the spherical tank are presented in (Fig. 8). Since FEM analysis identified dangers in the proposed design, experimental verification was needed in order to be absolutely certain that plastic deformations in supports will not cause failure of the structure.

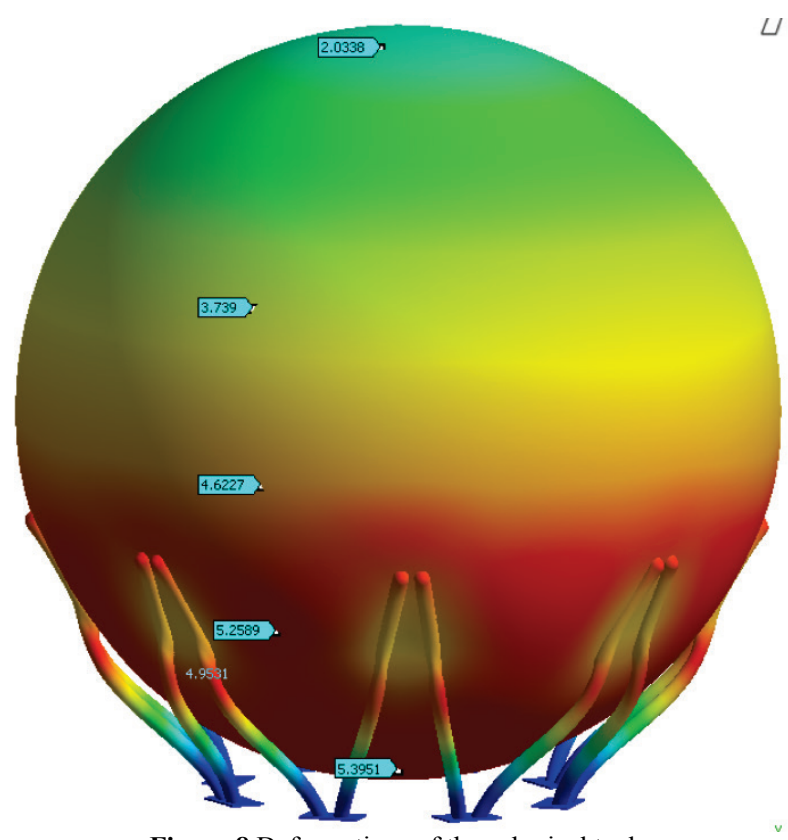

Figure 8 Deformations of the spherical tank

\subsection{Experimental verification}

Verification of analytical and the results obtained using the FEM model was performed by experimental testing of the spherical tank. As stated in previous section, for safety reasons, experiments were performed with water instead of propane-butane mixture.

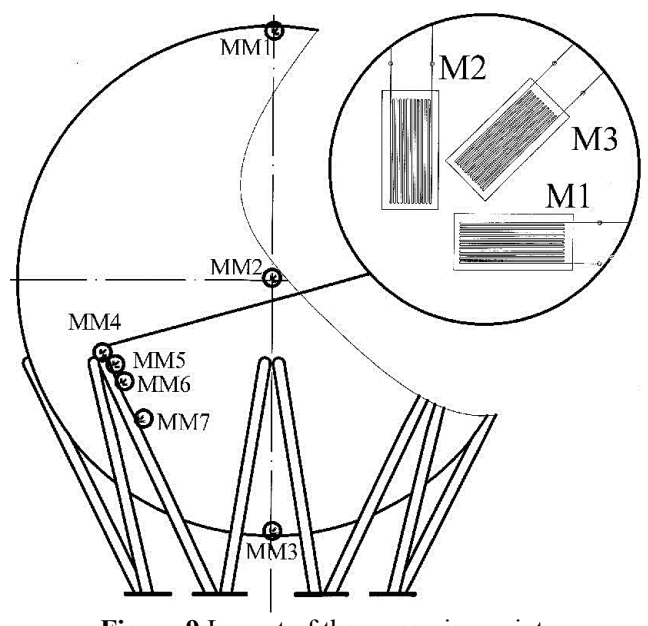

Figure 9 Layout of the measuring points

The experiment was carried out by measuring stresses at 7 measuring points with 21 strain gauges, by using the measuring equipment HBM UPM 100 [21]. The layout of the measuring points is shown in Fig. 9. This type of strain gauges setup makes measuring easier and does not require knowledge of the direction of the principal stresses propagation.

The strain gauges placed on spherical tank are shown in Fig. 10. 


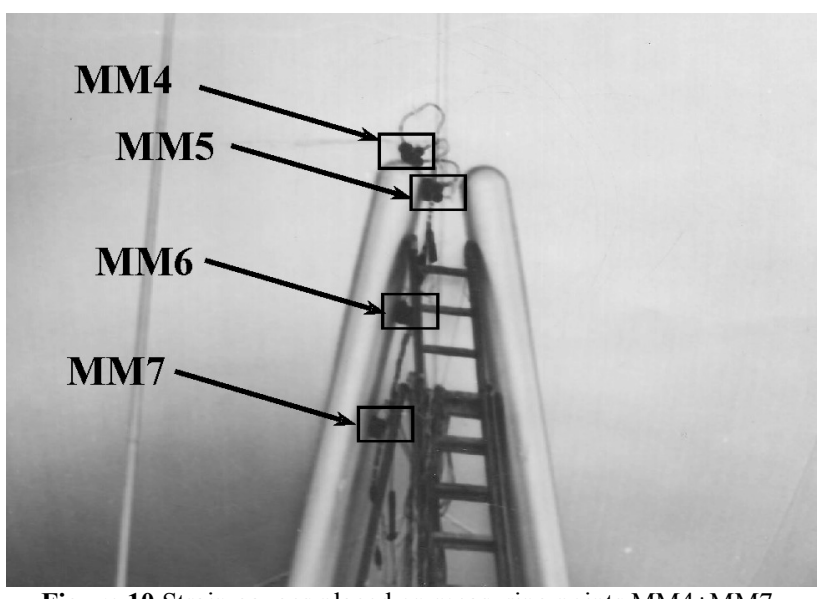

Figure 10 Strain gauges placed on measuring points MM4 $\div$ MM7

\section{Results and discussion}

The comparative values of stresses, for the operating pressure of $1,67 \mathrm{MPa}$, obtained analytically at the characteristic points, by FEM model and experimentally, are presented in Tab. 2.

Table 2 The comparative values of stresses obtained analytically, by FEM model and experimentally

\begin{tabular}{|c|c|c|c|}
\hline $\begin{array}{c}\text { Measuring } \\
\text { site }\end{array}$ & $\begin{array}{c}\sigma_{e} / \mathrm{MPa} \\
\text { Analytical }\end{array}$ & $\begin{array}{c}\sigma_{e} / \mathrm{MPa} \\
\text { FEM }\end{array}$ & $\begin{array}{c}\sigma_{e} / \mathrm{MPa} \\
\text { Experiment }\end{array}$ \\
\hline MM1 & 185,3 & 183,5 & 169,6 \\
\hline MM2 & 192,4 & 190,1 & 175,6 \\
\hline MM3 & 199,1 & 197,0 & 182,3 \\
\hline MM4 & - & 334,8 & 343,1 \\
\hline MM5 & 194,6 & 199,5 & 201,0 \\
\hline MM6 & 195,7 & 194,3 & 180,1 \\
\hline MM7 & 196,6 & 195,4 & 182,3 \\
\hline
\end{tabular}

Tab. 3 presents the percent deviation from the values of equivalent stresses obtained analytically and by FEM model in relation to the results obtained experimentally.

Table 3 Percent deviation of equivalent stresses obtained analytically and by using the FEM model in relation to the results obtained experimentally

\begin{tabular}{|c|c|c|}
\hline $\begin{array}{c}\text { Measuring } \\
\text { site }\end{array}$ & $\begin{array}{c}\text { Deviation of results } \\
\text { obtained analytically / \% }\end{array}$ & $\begin{array}{c}\text { Deviation of results } \\
\text { obtained by FEM / \% }\end{array}$ \\
\hline MM1 & 9,3 & 8,2 \\
\hline MM2 & 9,6 & 8,3 \\
\hline MM3 & 9,2 & 8,1 \\
\hline MM4 & - & 2,4 \\
\hline MM5 & 3,2 & 0,7 \\
\hline MM6 & 8,7 & 7,9 \\
\hline MM7 & 7,8 & 7,2 \\
\hline
\end{tabular}

Table 4 The equivalent values of stresses for the test pressure

\begin{tabular}{|c|c|c|c|}
\hline $\begin{array}{c}\text { Measuring } \\
\text { site }\end{array}$ & $\begin{array}{c}\sigma_{e} / \mathrm{MPa} \\
\text { Analytical }\end{array}$ & $\begin{array}{c}\sigma_{e} / \mathrm{MPa} \\
\text { FEM }\end{array}$ & $\begin{array}{c}\sigma_{e} / \mathrm{MPa} \\
\text { Experiment }\end{array}$ \\
\hline MM1 & 277,4 & 274,1 & 256,9 \\
\hline MM2 & 284,4 & 250,3 & 262,9 \\
\hline MM3 & 291,2 & 288,5 & 272,9 \\
\hline MM4 & - & 444,1 & 483,4 \\
\hline MM5 & 287,8 & 265,5 & 282,3 \\
\hline MM6 & 289,6 & 257,9 & 257,3 \\
\hline MM7 & 290,8 & 259,6 & 261,6 \\
\hline
\end{tabular}

The equivalent values of stresses for the test pressure of 2,5 $\mathrm{MPa}$ are presented in Tab. 4, and the deviations from the results obtained analytically and by using the FEM model in relation to the results obtained experimentally are presented in Tab. 5 .

Stress values obtained by experiments for some measuring sites are higher than analytical or FEM calculated stress, while for other sites they have lower value as shown in Tabs. 2 and 4. This disagreement is proof that experimental verification is necessary in order to be certain that proposed design will meet all safety requirements.

Table 5 Percent deviation of equivalent stresses obtained analytically and by FEM model in relation to the results obtained experimentally for the test pressure

\begin{tabular}{|c|c|c|}
\hline $\begin{array}{c}\text { Measuring } \\
\text { site }\end{array}$ & $\begin{array}{c}\text { Deviation of results } \\
\text { obtained } \\
\text { analytically / \% }\end{array}$ & $\begin{array}{c}\text { Deviation of results } \\
\text { obtained by using FEM / \% }\end{array}$ \\
\hline MM1 & 8,0 & 6,7 \\
\hline MM2 & 8,2 & 4,8 \\
\hline MM3 & 6,7 & 5,7 \\
\hline MM4 & - & 8,1 \\
\hline MM5 & 1,9 & 6,0 \\
\hline MM6 & 12,6 & 0,2 \\
\hline MM7 & 11,2 & 0,8 \\
\hline
\end{tabular}

From Tabs. 3 and 5 it can be clearly seen that FEM results are more accurate than analytical results in comparison to values obtained by experiments. FEM analysis is also much cheaper than construction and testing of prototype, it can identify critical areas and, if needed, modifications of design are easily and quickly conducted, so when prototype is constructed experiments are used to verify design and no further modifications on tank design are needed. In the case of analysed spherical tank the equivalent values of stresses at the point MM4 exceeded the values of yield stress, but not across the whole section (Fig. 7). The areas of local plastic deformation associated with stress concentrations are sufficiently small so there is no significant permanent deformation when the load is removed. Stress concentration predicted by FEM was also registered by experimental testing. Tank design was proved to be reliable, namely, because the measured values of equivalent stresses are, after eight months of exploitation (Tab. 2 and Tab. 4), identical to the original values after the installation of the spherical tank and its putting into operation.

\section{Conclusion}

The research carried out showed a high level of correspondence of the results obtained analytically and by FEM model with the results of experimental testing of spherical tanks. This correspondence of the results allows analytical expressions to be used for dimensioning spherical tanks. It is particularly important because, in a short period of time, in the initial design phase, the basic dimensions of the spherical tank can be obtained without carrying out an experiment and without FEM modeling. After the initial design phase, when all tank dimensions are known, more accurate FEM analysis is used to identify areas of high stress concentration. In the case of analyzed tank for pressure of 2,5 $\mathrm{MPa}$ equivalent stress exceeds yield stress at the points of tank connection with 
the supports. Since this high stress is concentrated in small region of connection area, associated plastic deformations are sufficiently small, so we draw a conclusion that this value of stress is not critical and that construction of spherical tank can proceed. After construction of spherical tank FEM results are verified with experiments. Experiments were repeated after 8 months confirming validity of the FEM conclusion that it is not necessary to reinforce the spherical tank at the points of its connection with the supports despite the fact that minor plastic deformation occurs. Methodology presented in this paper which utilizes advantages of analytical, numerical and experimental procedures, ensures fast design time, optimum dimensioning, and most importantly, safety within envisioned operating conditions.

\section{Acknowledgements}

The part of this research is supported by Ministry of Education, Science and Technological Development, Republic of Serbia, Grant TR32036.

\section{References}

[1] Shijian, Y.; Wang, F.; Wang, Z. R. Safety analysis of 200 $\mathrm{m}^{3}$ LPG spherical tank manufactured by the dieless hydrobulging technology. // Journal of Materials Processing Technology. 70, (1997), pp. 215-219. DOI: 10.1016/S09240136(97)02920-8

[2] Xiaodong, L.; Zhongshu, H.; Wenyi, D.; Anfeng, Y.; Peng, W. CFD Simulation of Temperature Field Distribution of the Liquefied Hydrocarbon Spherical Tank Leaking. // Procedia Engineering. 43, (2012), pp. 472-477. DOI: 10.1016/j.proeng.2012.08.081

[3] He, Z.; Yuan, S.; Wang, Z. R. Deformation of revolving closed-shell with multi-curvature profile under inner pressure. // Journal of Materials Processing Technology. 206, (2008), pp. 400-404. DOl: 10.1016/j.jmatprotec.2007.12.085

[4] Shirvill, L. C. Efficacy of water spray protection against propane and butane jet fires impinging on LPG storage tanks. // Journal of Loss Prevention in the Process Industries. $\quad 17, \quad$ (2004), pp. 111-118. DOl: 10.1016/j.jp.2003.10.004

[5] Curadelli, O.; Ambrosini, D. Damage detection in elevated spherical containers partially filled with liquid. // Engineering Structures. 33, (2011), pp. 2708-2715. DOI: 10.1016/j.engstruct.2011.05.023

[6] Portela, G.; Godoy, L. A. Wind pressures and buckling of cylindrical steel tanks with a dome roof. // Journal of Constructional Steel Research. 61, (2005), pp. 808-824. DOI: 10.1016/j.jcsr.2004.11.001

[7] Meløysund, V.; Lisø, K. R.; Hygen, H. O.; Høiseth, K.V.; Leira, B. Effects of wind exposure on roof snow loads, Building and Environment. 42, (2007), pp. 3726-3736. DOI: 10.1016/j.buildenv.2006.09.005

[8] Yang, Z. R.; Shou, B. N.; Sun, L.; Wang, J. J. Earthquake Response Analysis of Spherical Tanks with Seismic Isolation. // Procedia Engineering. 14, (2011), pp. 18791886. DOI: 10.1016/j.proeng.2011.07.236

[9] Virella, J. C.; Godoy, L. A.; Suarez, L. E. Dynamic buckling of anchored steel tanks subjected to horizontal earthquake excitation. // Journal of Constructional Steel Research. 62, (2006), pp. 521-531. DOl: 10.1016/j.jcsr.2005.10.001
[10] Petrovic, R.; Kojic, M.; Djordjevic, D. Design of tanks for storage and transport of fluid (in Serbian), Faculty of Mechanical Engineering Kraljevo, (2005).

[11] Timoshenko, S. P.; Woinowsky-Krieger, S. Theory of Plates and Shells, B\&JO Enterprise PTe ltd, 1985.

[12] Baličević, P.; Ivandić, Ž.; Kraljević D. Temperature transitional phenomena in spherical reservoir wall. // Tehnički vijesnik-Technical gazette. 17, 1(2010), pp. 31-34.

[13] Panthi, S. K.; Ramakrishnan, N.; Pathak, K. K.; Chouhan, J. $\mathrm{S}$. An analysis of springback in sheet metal bending using finite element method (FEM). // Journal of Materials Processing Technology. 186, (2007), pp. 120-124. DOI: 10.1016/j.jmatprotec.2006.12.026

[14] Kojic, M. An extension of 3-D procedure to large strain analysis of shells. // Computer methods in applied mechanics and engineering. 191, (2002), pp. 2247-2462. DOI: 10.1016/S0045-7825(01)00367-X

[15] Yoon, J. H.; Lee, H. S.; Yi, Y. M.; Jang, Y. S. Prediction of blow forming profile of spherical titanium tank. // Journal of Materials Processing Technology. 187-188, (2007). pp. 463-466. DOI: 10.1016/j.jmatprotec.2006.11.187

[16] Choubey, A.; Sehgal, D. K.; Tandon, N. Finite element analysis of vessels to study changes in natural frequencies due to cracks. // Journal of Pressure Vessels and Piping. 83, (2006), pp. 181-187. DOI: 10.1016/j.jpvp.2006.01.001

[17] Wang, Z. R.; Yushan, Z.; Yuansong, Z.; Shijian, Y. Experimental research and finite-element simulation of plates hidrobulging in pairs. // Journal of Pressure Vessels and Piping. 68, (1996), pp. 243-248. DOl: 10.1016/03080161(95)00073-9

[18] Kaptan, A.; Kisioglu, Y. Determination of burst pressures and failure locations of vehicle LPG cylinders. // Journal of Pressure Vessels and Piping. 84, (2007), pp. 451-459. DOI: 10.1016/j.jppvp.2007.02.004

[19] Zhang, S. H.; Nielsen, K. B.; Danckert, J.; Wang, Z. R. Numerical simulation of the integral hydro-bulge forming of non-clearance double-layer spherical vessels: deformation analysis. // Computers \& Structures. 70, (1999), pp. 243-256. DOI: 10.1016/S0045-7949(98)00159-X

[20] Pedersen, P. T.; Jensen, J. J. Buckling Behaviour of Imperfect Spherical Shells Subjected to Different Load Conditions. // Thin-Walled Structures, 23, (1995), pp. 4155. DOI: 10.1016/0263-8231(95)00003-V

[21] Internal documentation of the Waggon Factory Kraljevo Processing equipment, Kraljevo, 2006.

\section{Authors' addresses}

Radovan Petrović, PhD.

High School Trstenik

Radoja Krstića 19, 37240 Trstenik, Serbia

E-mail: petrovic.r@mfkv.kg.ac.rs

\section{Miroslav Živković, PhD. full professor}

University of Kragujevac, Faculty of Engineering

Sestre Janjic 6, 34000 Kragujevac, Serbia

E-mail: zile@kg.ac.rs

Marko Topalović

University of Kragujevac, Faculty of Engineering Sestre Janjic 6, 34000 Kragujevac, Serbia

E-mail: topalovic@kg.ac.rs

Radovan Slavković, PhD. full professor

University of Kragujevac, Faculty of Engineering

Sestre Janjic 6, 34000 Kragujevac, Serbia

E-mail: radovan@kg.ac.rs 